\title{
Having your cake and eating it, too. Over het weren van dual class- structuren uit aandelenindices
}

\author{
Mr. T.A. Keijzer*
}

\begin{abstract}
Enige tijd terug zijn verschillende samenstellers van aandelenindices consultatieprocedures gestart over de opname van beursvennootschappen met een dual class-aandelenstructuur. In deze bijdrage wordt de opkomst van het fenomeen indexbeleggen beschreven en betoogd dat het uitsluiten van dual class-vennootschappen het rendement van beleggers negatief zal beïnvloeden.
\end{abstract}

\section{Inleiding}

In deze bijdrage komen de gevolgen van een tweetal ontwikkelingen op de kapitaalmarkten aan de orde. De eerste ontwikkeling is de opkomst van het indexbeleggen. In dat geval wordt niet geïnvesteerd in individuele bedrijven, maar wordt de inleg gespreid over alle ondernemingen die in een index zijn opgenomen. De tweede ontwikkeling betreft de toegenomen populariteit van dual class-aandelenstructuren. Bij een dergelijke structuur bestaat het aandelenkapitaal uit een soort aandelen met meervoudig stemrecht (high-voting stock) en een soort met minder of geen stemrecht (low-voting stock). ${ }^{1}$ In reactie op deze verschuivingen zijn samenstellers van aandelenindices, waaronder zwaargewichten als S\&P Dow Jones, FTSE Russell en MSCI, bij (institutionele) investeerders te rade gegaan over de vraag of dual class-vennootschappen in een index vertegenwoordigd dienen te blijven. Dit consultatieproces heeft geresulteerd in een palet aan maatregelen. De voorstellen en maatregelen van S\&P Dow Jones, FTSE Russell en MSCI staan in deze bijdrage centraal. Ik begin met een rechtseconomische beschrijving van indexbeleggen (par. 2) en dual class-aandelenstructuren (par. 3). Vervolgens worden de voorstellen en maatregelen van S\&P Dow Jones, FTSE Russell en MSCI besproken (par. 4) en kritisch geanalyseerd (par. 5). Ik rond af in paragraaf 6 .

\footnotetext{
Mr. T.A. Keijzer is als promovendus verbonden aan de Sectie Ondernemingsrecht \& Financieel recht van de Erasmus School of Law, het Instituut voor Ondernemingsrecht ( $\mathrm{IvO}$ ) en het $\mathrm{IvO}$ Center for Financial Law \& Governance (ICFG).

1. Het onderscheid tussen superieur en inferieur stemrecht dient mijns inziens te worden beschouwd als een weberiaans ideaaltype (vgl. M.C.E. Weber, Gesammelte Aufsätze zur Wissenschaftslehre, Tübingen: Mohr Siebeck 1922, p. 190-198) en zegt op zichzelf nog vrij weinig over de concrete verdeling van zeggenschap.
}

\section{Indexbeleggen: beschrijving van een fundamentele verschuiving}

\subsection{Verschillende investeringsstrategieën}

Beleggers zijn op zoek naar rendement. ${ }^{2} \mathrm{Om}$ dat rendement te realiseren kunnen zij een strategie toepassen waarbij actief aandelen worden aangekocht en verkocht. Men kan bijvoorbeeld 'fundamenteel' beleggen of aan de hand van technische indicatoren. In het eerste geval kan worden gekeken naar (op basis van kwartaal- en jaarverslagen vast te stellen) koers-winstverhoudingen, boekwaarden en dividendrendementen. Een aandeel is dan mogelijk interessant op het moment dat de actuele ratio's gunstig afsteken bij de eigen historische kengetallen of die van concurrenten. ${ }^{3}$ Technische indicatoren hebben betrekking op gebeurtenissen in de markt zelf, bijvoorbeeld het vormen van bepaalde patronen in de beurskoers, in plaats van ontwikkelingen bij de onderneming. ${ }^{4}$ Andere actieve strategieën (of een combinatie daarvan) zijn uiteraard eveneens denkbaar. Uit empirisch onderzoek blijkt echter dat weinig actieve beleggers in staat zijn op de lange termijn de 'markt te verslaan'. 5 Dit geldt zowel wanneer zij zelf de beleggingsbeslissing nemen als wanneer dit proces wordt gedelegeerd (ook in

2. Zie de titel van de klassieker van Easterbrook \& Fischel (F.H. Easterbrook \& D.R. Fischel, The economic structure of corporate law, Cambridge: Harvard University Press 1991). Voor besloten verhoudingen zijn uitzonderingen denkbaar; vgl. het winstrechtloze aandeel van art. 2:216 lid 7 BW. Bij de invoering van de Wet Flex-BV werd daarover opgemerkt dat zo'n instrument nuttig zou kunnen zijn om opvolgingsconstructies in de familiale sfeer te faciliteren. Zie Kamerstukken II 2006/07, 31058, 3 , p. 75.

3. Zie over value investing B. Graham \& D. Dodd, Security analysis, New York: McGraw-Hill 1934; B. Graham, The intelligent investor, New York: Harper 1949; Halliburton Co. v. Erica P. John Fund, Inc., 573 U.S. __ (2014). Deze benadering staat op gespannen voet met de efficient capital market hypothesis van Fama (E.F. Fama, Efficient capital markets: A review of theory and empirical work, The Journal of Finance (25) 1970, p. 383-417). Zie over deze spanning bijv. J. Lakonishok, A. Shleifer \& R.W. Vishny, Contrarian investment, extrapolation and risk, in: R.H. Thaler, Advances in behavioral finance, New York: Princeton University Press 2005, p. 273-316.

4. Zie R.D. Edwards, J. Magee \& W.H.C. Bassetti, Technical analysis of stock trends, New York: CRC Press 2007, p. 4.

5. Vgl. bijv. K.R. French, Presidential address: The cost of active investing, The Journal of Finance (63) 2008, p. 1537-1573, die stelt dat in de periode 1980-2006 een investeerder zijn jaarlijks rendement met $0,67 \%$ kon verhogen door passief te beleggen. 


\section{Maandblad}

Ondernemingsrecht

verband met de in dat geval verschuldigde, niet-geringe beheervergoedingen ${ }^{6}$ ).

\subsection{Vormen van passief beleggen}

Veel investeerders hebben, gelet op het voorgaande, gekozen voor een passieve strategie. ${ }^{7} \mathrm{Zij}$ beleggen niet langer in individuele aandelen, maar investeren in een fonds dat een bepaalde index vertegenwoordigt of nabootst. Dit zijn de zogenaamde index trackers en Exchange-Traded Funds (ETF's). Index trackers en ETF's kunnen onder meer verschillen qua samenstelling en verhandelbaarheid. Wat betreft de samenstelling kan een onderscheid worden gemaakt tussen fysieke replicatie, wanneer alle onderliggende aandelen daadwerkelijk in de juiste verhouding aanwezig zijn, en synthetische replicatie. In het laatste geval wordt gebruik gemaakt van vervangende instrumenten zoals opties. In beide gevallen slaagt het replicatieproces grotendeels, maar nooit volledig, onder meer door beheersen transactiekosten en belastingen. Het verschil staat bekend als de tracking error. ${ }^{8}$ Inzake de verhandelbaarheid geldt het volgende onderscheid. Handel in ETF's vindt de hele dag plaats; de prijs van het instrument wordt bepaald door vraag en aanbod. In index trackers kan enkel aan het einde van de dag worden gehandeld tegen de waarde van de onderliggende aandelen. Een verschil is voorts de wijze waarop dagelijkse onttrekkingen en stortingen worden verwerkt. Bij index trackers geschiedt dit doordat de beheerder aandelen koopt respectievelijk verkoopt, met transactiekosten voor blijvende deelnemers tot gevolg. Bij ETF's worden mutaties afgehandeld doordat geselecteerde financiële instellingen (authorized participants) arbitreren op de prijs van de ETF ten opzichte van de onderliggende aandelen. Aldus worden transactiekosten voor zittende deelnemers afgewend. ${ }^{9}$ Index trackers en ETF's hebben verschillende voordelen. De jaarlijkse kosten ten opzichte van actief beheerde beleggingsfondsen zijn laag. ${ }^{10}$ Bovendien leiden zij, wanneer de opgenomen instrumenten qua prijsvor-

6. Hoewel onderling aanzienlijke verschillen bestaan, bedragen de kosten voor actief beheerde mutual funds veelal $1-2 \%$ per jaar; voor hedge funds is de jaarlijkse vergoeding (die bestaat uit een vast en een variabel deel) in totaal 3-4\%. Zie French 2008.

7. Zie bijv. I.R. Appel, T.A. Gormley \& D.B. Keim, Passive investors, not passive owners, Journal of Financial Economics (121) 2016, p. 111-141, waar naar voren komt dat in de VS de marktwaarde van passief beheerde fondsen tussen 1998 en 2014 verviervoudigde; zie ook C. Schmidt \& R. Fahlenbrach, Do exogenous changes in passive institutional ownership affect corporate governance and firm value?, Journal of Financial Economics (124) 2017, p. 285-306, die in de periode 2007-2013 voor US ETFs een netto-instroom melden van $\$ 795$ miljard, waar de netto-uitstroom voor actief beheerde mutual funds $\$ 575$ miljard bedroeg; H.T.C. Hu \& J. Morley, A regulatory framework for exchange-traded funds, 2018, beschikbaar op www.ssrn.com, die gelet op het toegenomen belang van ETF's gedetailleerde voorstellen doen voor regulering.

8. Zie bijv. A.P. Fassas, Tracking ability of ETFs: Physical versus synthetic replication, The Journal of Index Investing (5) 2015, p. 9-20.

9. Zie I. Ben-David, F. Franzoni \& R. Moussawi, Exchange-traded funds, Annual Review of Economics (9) 2017, p. 169; voorts eerder A. Agapova, Conventional mutual index funds versus exchange traded funds, Journal of Financial Markets (14) 2011, p. 323-343; L. Kostovetsky, Index mutual funds and exchange-traded funds, The Journal of Portfolio Management (29) 2003, p. 80-92.

10. Meestal 0,1-0,2\%. Zie French 2008. Vgl. ook noot 6 . ming niet volledig correleren, tot een grotere diversificatie. ${ }^{11}$ Opgemerkt zij overigens dat sommige fondsen pretenderen een actieve strategie te hanteren, maar in feite de bredere index volgen (closet indexing). ${ }^{12}$ Daarmee is het onderscheid tussen actief en passief meer gradueel van aard. ${ }^{13}$

\subsection{Indexsamenstelling}

S\&P Dow Jones, FTSE Russell en MSCI zijn alle zwaargewichten wat betreft de samenstelling van aandelenindices. S\&P Dow Jones is onder meer verantwoordelijk voor de samenstelling van de Dow Jones en de S\&P 500. Beide worden bij uitstek gezien als graadmeter voor de Amerikaanse economie. FTSE Russell stelt bijvoorbeeld de FTSE 100 samen, die de Engelse markt vertegenwoordigt. Beide instellingen hebben van oudsher sterke banden met de journalistiek, respectievelijk de Wall Street Journal en de Financial Times. MSCI is vooral bekend van de MSCI World Index, die de stand van de wereldeconomie belichaamt. Als zodanig genieten de drie een enorme reputatie onder beleggers. Vanzelfsprekend hebben zij alle uitgebreide methoden ontwikkeld om de verschillende indices samen te stellen. ${ }^{14}$ In die zin dienen aanvullende vereisten omtrent het stemrecht slechts te worden beschouwd als onderdeel van een groter geheel. Voorafgaand aan de hier te bespreken ontwikkelingen vormden met name de beurswaarde en, daarmee samenhangend, liquiditeit een belangrijk criterium om tot indexopname over te gaan. Daarbij is het indexgewicht van vennootschappen met de hoogste beurswaarde substantieel zwaarder dan dat van de vennootschappen met de laagste beurswaarde. Deze benadering kan tot bijzondere uitkomsten leiden. Zo zijn de ondernemingen 750 tot en met 1000 in de Russell 1000 opgenomen; aldaar zijn zij van bescheiden belang. De ondernemingen 1001 tot en met 1250 , die qua beurswaarde weinig verschillen van de ondernemingen 750 tot en met 1000 , vallen daarentegen in de Russell 2000 en hebben daar het hoogste gewicht. ${ }^{15}$ Dat een selectie gebaseerd op marktkapitalisatie wonderlijke gevolgen kan hebben, is door de indexbouwers zelf ook onderkend. Zij hebben daarom hun productaanbod uitgebreid. MSCI biedt indices aan waarin aandelen een gelijk gewicht kennen, maar ook indices gebaseerd op een bepaalde regio (developed,

11. Vgl. voor de wortels van Modern Portfolio Theory H. Markowitz, Portfolio selection, The Journal of Finance (7) 1952, p. 77-91.

12. Zie bijv. M. Cremers e.a., Indexing and active fund management: International evidence, Journal of Financial Economics (120) 2016, p. 539-560.

13. Zie noot 1 .

14. Vgl. ter illustratie onder meer http://us.spindices.com/documents/ methodologies/methodology-sp-us-indices.pdf (opgesteld door S\&P Dow Jones), voor FTSE Russell www.ftse.com/products/downloads/RussellUS-indexes.pdf en voor wat betreft MSCI www.msci.com/eqb/ methodology/meth_docs/MSCI_USEI_Methodology_Feb18.pdf. Opgemerkt zij echter dat het in alle gevallen 'slechts' de US Equity Indices betreft. Er zijn uiteraard vele andere documenten omtrent indexmethodologie beschikbaar.

15. Zie Appel, Gormley \& Keim 2016, die bijv. ook opmerken dat terwijl de marktkapitalisatie van de ondernemingen opgenomen in de Russell 1000 ongeveer tienmaal zo hoog ligt als de marktkapitalisatie van ondernemingen in de Russell 2000, de waarde van indexfondsen aangaande de Russell 1000 slechts twee tot driemaal hoger is. 
emerging en frontier markets), factoren (volatiliteit, momentum en waarde) of thema's (religie). ${ }^{16}$ In totaal biedt MSCI omstreeks 190.000 indexproducten aan.

\section{Dual class-structuren: traditionele voor- en tegenargumenten bij een recente opleving}

\subsection{Recente ontwikkelingen}

Sinds geruime tijd vindt een intensieve discussie plaats over dual class-aandelenstructuren. In de VS verliep het debat daarover goeddeels in twee fasen, de eerste in de jaren twintig (toen de steen des aanstoots werd gevormd door de kapitaalstructuur van Dodge) en de tweede in de jaren tachtig (midstream herkapitalisatie door General Motors). ${ }^{17}$ Men zou kunnen betogen dat er sinds enige jaren een derde fase gaande is. ${ }^{18}$ Een recente ontwikkeling daarin vormt Snap Inc. (het moederbedrijf van Snapchat), dat in het kader van zijn beursgang in maart 2017 enkel stemrechtloze aandelen (A) bij het beleggende publiek plaatste. De aandelen met enkelvoudig stemrecht (B) worden gehouden door venture capital-investeerders en werknemers. Aandelen met meervoudig stemrecht (C) zijn in handen van de oprichters. ${ }^{19}$

\subsection{Traditionele voor-en tegenargumenten}

Een kapitaalstructuur bestaande uit high-en low-voting stock kent zowel voor- als nadelen. Het MSCI-rapport biedt daarvan een aardig overzicht. ${ }^{20}$ Een op de agency-theorie gebaseerd

16. Zie www.msci.com/indexes; vgl. voor S\&P Dow Jones http://us.spindices com/index-finder/; zie voor FTSE Russell www.ftse.com/products/ indexmenu?. De Verordening financiële benchmarks (Verordening (EU) 2016/1011) legt bij de samenstelling van indices weliswaar zorgvuldigheids- en consistentie-eisen, maar geen inhoudelijke eisen op.

17. Zie W.Z. Ripley, Main Street and Wall Street, Boston: Little Brown 1927 en J. Seligman, Equal protection in shareholder voting rights: The one common share, one vote controversy, George Washington Law Review (54) 1986, p. 687-724. De herkapitalisatie van General Motors (in de vorm van aandelen met minder stemrecht) leidde tot SEC Rule 19c-4, waardoor het niet langer mogelijk werd effecten ter beurze te verhandelen wanneer de stemrechten van zittende aandeelhouders werden ingeperkt. Zie over de nasleep daarvan - in 905 F.2d 406 (D.C. Cir. 1990) (Business Roundtable v. SEC) werd de regeling succesvol aangevochten - bijv. S.M. Bainbridge, The short life and resurrection of SEC Rule 19C-4, Washington University Law Review (69) 1991, p. 565-634.

18. In die zin W-G. Ringe, Deviations from ownership-control proportionality: Economic protectionism revisited, in: U. Bernitz \& W-G. Ringe, Company law and economic protectionism: New challenges to European integration, Oxford: Oxford University Press 2010, p. 231. Ook in Nederlandse juridische tijdschriften komen dual class-aandelenstructuren de laatste jaren regelmatig aan de orde. Vgl. over het hier besproken onderwerp eveneens J.M. de Jongh, Aanpassing MSCI-indices bij dual class shares, Ondernemingsrecht 2018/47.

19. Zie daarover L.A. Bebchuk \& K. Kastiel, The perils of small-minority controllers, 2018, beschikbaar via www.ssrn.com; D. Lund, Nonvoting shares and efficient corporate governance, 2017, beschikbaar via www. ssrn.com (hierna: Lund 2017a); B.S. Sharfman, A private ordering defense of a company's right to use dual class share structures in IPOs, 2017 beschikbaar via www.ssrn.com; L.A. Bebchuk \& K. Kastiel, The untenable case for perpetual dual-class stock, Virginia Law Review (103) 2017, p. 585-631. Zie voor een analyse vanuit Nederlands perspectief A.A Bootsma \& T.A. Keijzer, Snap Inc. De eerste beursgang met stemrechtloze aandelen in de V.S., Ondernemingsrecht 2017/68.

20. Vgl. noot 36 . nadeel is dat dual class-mechanismen het verwerven van private benefits of control in de hand werken. ${ }^{21}$ Dat houdt in dat controlerende aandeelhouders zichzelf bepaalde voordelen kunnen toekennen (zij beheersen immers de besluitvorming) zonder de daaraan verbonden economische consequenties volledig te hoeven dragen. ${ }^{22}$ Het verwerven van deze voordelen kan op verschillende manieren geschieden, bijvoorbeeld in vorm van het toe-eigenen van bedrijfsactiva tegen een nietmarktconforme prijs (tunneling) ${ }^{23}$ of het vergroten van de omvang van de onderneming om aldus meer prestige en een hogere beloning te verkrijgen (empire building). ${ }^{24}$ Bovendien schakelen dual class-structuren de werking van de market for corporate control uit. ${ }^{25}$ Aandeelhouders kunnen het zittende bestuur - vanwege het gebrek aan zeggenschapsrechten immers niet vervangen door een ander, efficiënter gezelschap. Anderzijds stellen dual class-mechanismen controlerende aandeelhouders in staat om hun mogelijk unieke langetermijnvisie - in de literatuur wordt wel gesproken van idiosyncratic vision $^{26}$ - te implementeren, zonder het risico te lopen dat midscheeps discussie ontstaat met investeerders die een andere opvatting zijn toegedaan. Voorstanders van deze benadering benadrukken dat gestreefd dient te worden naar een evenwicht tussen initiatief en controle. ${ }^{27}$ Bovendien vormt de aan-

21. Zie over het concept van private benefits bijv. L.A. Bebchuk, R. Kraakman \& G. Triantis, Stock pyramids, cross-ownership and dual class equity: The mechanisms and agency costs of separating control from cash-flow rights, in: R.K. Morck (red.), Concentrated corporate ownership, Chicago: Chicago University Press 2000, p. 445-460; A. Shleifer \& R.W. Vishny, A survey of corporate governance, The Journal of Finance (52) 1997, p. 737-783; K. Geens \& C. Clottens, One share - one vote: Fairness, efficiency and (the case for) EU harmonisation revisited, 2010, beschikbaar op www.ssrn.com.

22. Zie uitgebreid Bebchuk \& Kastiel 2018, die laten zien dat naarmate het economisch belang van de controlerende aandeelhouder afneemt (bijv. van $75 \%$ naar $70 \%$ of van $15 \%$ naar $10 \%$ ) de aantrekkingskracht van private benefits exponentieel toeneemt.

23. Zie S. Johnson e.a., Tunneling, The American Economic Review (90) 2000, p. 22-27; vgl. vanuit Nederlands perspectief J.W. Winter, Tunneltjes graven, Ondernemingsrecht 2001, afl. 8, p. 217-218.

24. Private benefits kunnen overigens ook niet-monetair van aard zijn. Vgl. R.J. Gilson, Controlling shareholders and corporate governance: Complicating the comparative taxonomy, Harvard Law Review (119) 2006, p. 1641-1679.

25. Vgl. voor de oorsprong van dat begrip H.G. Manne, Mergers and the market for corporate control, Journal of Political Economy (73) 1965, p. 110-120. Zie voor het verschil met de market for corporate influence B.R. Cheffins \& J. Armour, The past, present and future of shareholder activism by hedge funds, Journal of Corporation Law (37) 2011, p. 51-103.

26. Zie Z. Goshen \& A. Hamdani, Corporate control and idiosyncratic vision, Yale Law Journal (125) 2016, p. 560-617; zie ook Z. Goshen \& R. Squire, Principal costs: A new theory for corporate law and governance, Columbia Law Review (117) 2017, p. 767-829; eerder vergelijkbaar A.M. Pacces, Rethinking corporate governance: The law and economics of control powers, Londen: Routledge 2012, p. 93-94.

27. In die zin bijv. R.J. Gilson \& A. Schwartz, Constraints on private benefits of control: Ex ante control mechanisms versus ex post transaction review, Journal of Institutional and Theoretical Economics (169) 2013, p. 160-183; zie eerder ook M. Burkart, D. Gromb \& F. Panunzi, Large shareholders, monitoring, and the value of the firm, Quarterly Journal of Economics (112) 1997, p. 693-728; H. DeAngelo \& L. DeAngelo, Managerial ownership of voting rights: A study of public corporations with dual classes of common stock, Journal of Financial Economics (14) 1985, p. 33-69. 


\section{Maandblad \\ Ondernemingsrecht}

koop van low-voting stock een vrijwillige keuze, gemaakt door rationele personen in een vrije markt. ${ }^{28}$ Empirische studies naar de waardering van dual class-structuren bieden geen eenduidig beeld over de effecten daarvan. ${ }^{29}$

\section{S\&P Dow Jones, FTSE Russell \& MSCI: voorstellen en maatregelen}

\subsection{S\&P Dow Jones}

De S\&P Dow Jones vaardigde als eerste een consultatiedocument uit, op 3 april 2017. ${ }^{30}$ De bevindingen werden 31 juli bekendgemaakt en traden onmiddellijk in werking. ${ }^{31}$ De S\&P Global BMI Indices en de S\&P Total Market Index zullen vennootschappen met dual class-aandelenstructuren (inclusief stemrechtloze aandelen) blijven opnemen. Voor de S\&P Composite 1500 en de componenten daarvan (S\&P 500, S\&P MidCap 400 en S\&P SmallCap 600) is dat niet het geval. Een onderscheid tussen de situatie dat enkel stemrechtloze aandelen ter beurze worden verhandeld en dat ook gehandeld kan worden in aandelen met (meervoudig) stemrecht is niet aan de orde. Wel wordt voorzien in eerbiedigende werking (grandfathering). Aan deze keuzes ligt ten grondslag dat de S\&P Global BMI Indices en de S\&P Total Market Index het 'universum' aan investeringsmogelijkheden dienen te vertegenwoordigen; governance-overwegingen zouden daarbij geen rol moeten spelen. Voor de S\&P Composite 1500 (en de componenten daarvan) gelden reeds eisen ten aanzien van bijvoorbeeld het deel van de aandelen dat vrij verhandelbaar is (free float); dit dient minimaal 50\% te bedragen. Aanvullende maatregelen zouden dan een kleinere stap vormen.

\subsection{FTSE Russell}

FTSE Russell overwoog dat het opnemen van vennootschappen waarvan het kapitaal gedeeltelijk bestaat uit stemrechtloze aandelen in aandelenindices weinig problematisch is. ${ }^{32}$ Zo vormen preferente aandelen een vertrouwd instrument en kan het gebruik van stemrechtloze aandelen in ontwikkelende markten noodzakelijk zijn om te voldoen aan beperkingen omtrent buitenlandse zeggenschap. De governance-implicaties

28. Tegengeworpen kan worden dat wanneer een passieve beleggingsstrategie wordt gehanteerd het besluit tot aankoop van een individueel instrument geen rationele keuze vormt. Anderzijds is de initiële keuze voor een passieve strategie dat wel (vgl. French 2008). Zie ook Bebchuk \& Kastiel 2017, die opmerken dat naarmate de dual class-structuur gecompliceerder wordt (door sunset-mechanismen e.d.) een steeds sterkere variant van de efficient capital market hypothesis (vgl. Fama 1970) vereist is.

29. Vgl. R. Adams \& D. Ferreira, One share - one vote: The empirical evidence, Review of Finance (12) 2008, p. 51-91. Zie ook Bootsma \& Keijzer 2017 voor de alhier besproken materie. Voor een kritische analyse van de agency theory, zie J.M. de Jongh, Tussen societas en universitas. De beursvennootschap en haar aandeelhouders in historisch perspectief (diss. Rotterdam), Deventer: Kluwer 2014, p. 406 e.v.

30. Via http://us.spindices.com/documents/index-news-and-announce ments/20170403-spdji-eligibility-non-voting-share-classes-consultation. pdf kan het consultatiedocument worden geraadpleegd.

31. Een overzicht van de genomen maatregelen is beschikbaar via www.spiceindices.com/idpfiles/spice-assets/resources/public/documents/561162_ spdjimulti-classsharesandvotingrulesannouncement7.31.17.pdf.

32. Zie hiervoor http://storage.pardot.com/6522/175581/FTSE_Russell Voting_Rights_Consultation_June_2017.pdf. van stemrechtloze aandelen zouden echter problematisch kunnen worden op het moment dat het stemrecht in handen van free float investors beneden een bepaalde drempel raakt. Daarom werd op 26 juli 2017 bekendgemaakt dat vennootschappen uit ontwikkelde landen waar free float investors minder dan $5 \%$ van de stemrechten in handen hebben per september niet langer kwalificeren voor opname in een index. ${ }^{33}$ De voorwaarde van een free float met $5 \%$ van het stemrecht geldt reeds voor de FTSE Global Equity Index Series en de Russell 3000. Een drempel van 25\% (conform de FTSE UK Index Series), wat de voorkeur had van 55\% van de respondenten die het invoeren van een drempel steunden, werd te verstorend geacht. ${ }^{34}$ De uitsluiting ziet ook hier op alle soorten aandelen, hoewel daarover geen duidelijke voorkeur bestond. ${ }^{35} \mathrm{Bij}$ het berekenen van het totaal aantal uit te brengen stemmen dienen eveneens niet ter beurze verhandelbare aandelen in aanmerking te worden genomen. Er wordt voorzien in een overgangsperiode tot september 2022. Jaarlijks wordt geëvalueerd of een hogere drempel dan 5\% gepast is. FTSE Russell sprak van een 'pragmatisch compromis'.

\subsection{MSCI}

Het oorspronkelijke MSCI-voorstel zag specifiek op de Global Investable Markets Index (GIMI) en US Equity Indexes. ${ }^{36}$ Weliswaar stelde MSCI net als FTSE Russell een stemrechtdrempel voor van $25 \%$ (voor ontwikkelde markten), maar dit percentage betrof de beursgenoteerde aandelen als geheel en niet enkel de free float. Wanneer aan dat vereiste niet zou zijn voldaan, zouden enkel stemrechtloze aandelen worden geweerd. Voor bestaande vennootschappen zou een vereiste van twee derde van $25 \%$ gelden (dat is $16,67 \%$ ), dat na een overgangstermijn van één jaar zou moeten ingaan. Ook werden door MSCI vragen opgeworpen inzake onderwerpen als de hoogte van de stemrechtdrempel, de overgangstermijn en grandfathering (vergelijk hierboven). Daarnaast was er aandacht voor meer exotische themata, bijvoorbeeld of aandelen met een minimaal (maar in theorie aanwezig) stemrecht ${ }^{37}$ of stemrecht dat enkel ziet op bepaalde onderwerpen, ${ }^{38}$ ook als stemrechtloos aangemerkt dienen te worden, en zelfs of stemrechtloze aandelen als eigen vermogen hebben te gelden. De consultatieronde sloot per 31 augustus 2017. Althans, zo leek het, want in november 2017 werd aangekondigd dat het con-

33. Vgl. www.ftse.com/products/downloads/FTSE_Russell_Voting_Rights_ Consultation_Next_Steps.pdf. Visuele resultaten zijn te raadplegen via www.ftse.com/products/downloads/FTSE_Russell_Voting_Rights_ Consultation_Results.pdf.

34. Een drempel van $5 \%$ zou 32 vennootschappen treffen; een drempel van $25 \%$ nog eens 123 (totaal 155). Zie voor een overzicht www.ftse.com/ products/downloads/Indicative_List_of_Affected_Securities.xlsx.

35. Optie (1), volledig weren uit de index, had de voorkeur van $29 \%$; (2) verminderen indexgewicht: $21 \%$; (3) enkel weren stemrechtloze aandelen: $31 \%$; (4) combinatie (2) en (3): $13 \%$.

36. Vgl. www.msci.com/documents/1296102/1220bc04-83bd-44c1-8527a4014ef51c8d. Opgemerkt zij dat het tweede herziene voorstel (zie hieronder) een groter aantal indices omvat.

37. Vgl. G.J.W. Kinnegim, De flex-bv fiscaal getoetst, Ondernemingsrecht 2007/119, die hiervoor de term 'nihilaandelen' hanteert; vgl. ook noot 1.

38. Zie Kamerstukken II 2006/07, 31058, 3, p. 12, waar althans wat de BV betreft aan de orde komt dat dergelijke instrumenten niet zijn toegestaan. 
sultatieproces in bredere vorm heropend zou worden. ${ }^{39}$ In januari 2018 werd het herziene voorstel gepresenteerd. ${ }^{40}$ Aandelen die qua stemrecht afwijken van het principe van proportionaliteit blijven daarin in aanmerking komen voor indexopname. In plaats daarvan werd voorgesteld het indexgewicht aan te passen naar rato van het stemrecht van de free float. ${ }^{41}$ Aldus blijven indices een breed spectrum aan investeringsmogelijkheden vertegenwoordigen en wordt een drempel met een arbitrair karakter (5\%, 25\% of 50\%) voorkomen. Voorts wordt opgemerkt dat vanuit historisch oogpunt de aanwezigheid van stemrecht evenmin noodzakelijk is voor kwalificatie van het aandeel als eigen vermogen. ${ }^{42}$ Anderzijds is het stemrecht voor veel aandeelhouders van fundamenteel belang, en des te meer voor indexbeleggers, aangezien zij hun stukken niet kunnen verkopen. Aandelen die slechts stemrecht ten aanzien van bepaalde onderwerpen of voorwaardelijk stemrecht (bijvoorbeeld wanneer geen dividend is uitgekeerd) kennen, worden volledig als stemrechtloos aangemerkt. Er geldt een uitzondering voor ontwikkelende markten en loyaliteitsaandelen. Het eerste herziene voorstel zou, gemeten naar beurswaarde, $4-5 \%$ van de markt raken, hoewel de gevolgen per land aanzienlijk kunnen verschillen. ${ }^{43}$ Er werd voorzien in een overgangsperiode van drie jaar. De nieuwe consultatieronde liep tot 31 mei 2018. Op 21 juni 2018 werd echter bekendgemaakt dat de consultatieperiode wederom werd verlengd, ditmaal tot 28 september 2018 , en dat de resultaten uiterlijk 31 oktober bekend zouden worden gemaakt. ${ }^{44}$ Onduidelijk is overigens waarin het tweede herziene voorstel precies verschilt van het eerste. De onderhuidse aanpassingen zijn echter niet zonder belang. De effecten voor specifiek Nederlandse beursvennootschappen zijn namelijk substantieel kleiner (index turnover van $2 \%$ versus $12 \%$ ).

39. Zie www.msci.com/documents/10199/02bacb99-1b53-4c91-b82d -2a1c64dc0825; zie ook D. Melas, Summary of MSCI consultation paper on voting rights and index inclusion, 2018, beschikbaar op http:// corpgov.law.harvard.edu/.

40. Vgl. www.msci.com/documents/1296102/8328554/Consultation Voting+Rights.pdf. Zie ook het door MSCI gepubliceerde consultation discussion paper, met aandacht voor (empirische) literatuur omtrent dual class-structuren, beschikbaar via www.msci.com/documents/ 1296102/8328554/Discussion+Paper_Voting+rights.pdf.

41. Daaruit volgt dat wanneer ter beurze enkel stemrechtloze aandelen worden verhandeld, wel wordt overgegaan tot schrapping.

42. Zie ook art. 2:23b BW: beslissend voor de vraag of sprake is van eigen vermogen, is of de ingebrachte fondsen risicodragend zijn. Dat is ook het geval indien de aandeelhouder de (contractuele of statutaire) mogelijkheid heeft de kapitaalverschaffing te beëindigen (redeemable shares), wanneer het recht bijv. ten aanzien van de vergoeding gelijkenissen vertoont met een lening, of als het risico dat ingebrachte gelden worden aangesproken ter betaling van schulden verwaarloosbaar lijkt (een contractueel liquidatierecht). Zie HR 7 februari 2014, ECLI:NL:HR:2014:181, V-N 2014/9.12, BNB 2014/80 m.nt. De Vries, FED 2014/38 m.nt. Marres en HR 7 februari 2014, ECLI:NL:HR:2014:224, V-N 2014/9.13, BNB 2014/79 m.nt. De Vries, FED 2014/37 m.nt. Marres. (Dit betreft weliswaar fiscale zaken, maar zij draaiden om de fiscaal toe te passen civielrechtelijke maatstaf.)

43. Zo zijn de consequenties voor de Zweedse (10\%), Zwitserse (14\%) en Deense (22\%) markt aanzienlijk.

44. Vgl. www.msci.com/index-announcements. Zie ook noot 40 (de hyperlink aldaar verwijst naar zowel het eerste als het tweede voorstel voor herziening).

\subsection{Procedurele observaties}

Het is allereerst interessant om te zien dat het met name institutionele beleggers zijn die actief hebben deelgenomen aan het relatief korte en weinig zichtbare consultatieproces. ${ }^{45} \mathrm{Zij}$ zien het principe van one share, one vote veelal als een fundamenteel onderdeel van een gezonde governance. ${ }^{46}$ Vanuit Nederlandse institutionele beleggers klinken vergelijkbare geluiden. ${ }^{47}$ Opgemerkt zij echter dat ook een tegengestelde beweging zichtbaar is. Vermogensbeheerder BlackRock stelde dat het niet aan samenstellers van indices is om stelling te nemen in het one share, one vote-debat. ${ }^{48}$ De beurs van Hong Kong heeft het traditionele verbod op dual class-aandelenstructuren in 2017 opgeheven. Met het oog op het aantrekken van innovatieve, groeiende ondernemingen wordt het onder strikte voorwaarden mogelijk dergelijke instrumenten uit te geven. ${ }^{49}$ In Singapore worden dergelijke mechanismen sinds kort eveneens toegestaan, wanneer het een secundaire notering betreft. 50 Daarnaast is het opvallend dat de maatregelen van S\&P Dow Jones (opname dual class-vennootschappen in sommige indices, in andere niet), FTSE Russell (introductie 5\% free float-stemrechtdrempel voor alle indices) en het oorspronkelijke en wederom herziene voorstel van MSCI (introductie 25\%stemrechtdrempel respectievelijk vermindering van het indexgewicht) onderling substantiële verschillen vertonen. Dat wijst er immers op dat consensus over de vraag hoe om te gaan met dual class-mechanismen in indexverband afwezig is. Deze

45. Zie ook de verzoeken van de Council of Institutional Investors (beheerd vermogen leden: \$ 3 biljoen) aan FTSE Russell van 24 maart 2017 en MSCI (29 maart 2017) om consultatieprocessen in gang te zetten. Zie www.cii.org/dualclass_stock.

46. In het kader van het S\&P Dow Jones-consultatieproces stelde het International Corporate Governance Network (ICGN), een organisatie waarvan de institutionele leden $\$ 26$ biljoen aan bezittingen beheren, dat 'it has long advocated a preference for the "one share, one vote" standard as the optimal structure for companies wishing to benefit from access to public capital'. De volledige consultatiereactie van het ICGN (gedateerd op 3 mei 2017) kan online worden geraadpleegd via www.icgn.org/sites/ default/files/6.\%20S\%26P\%20index\%20consultation\%20on\%20dual \%20class\%20shares\%20May\%202017_0.pdf. Zie voor vergelijkbare uitingen de literatuur aangehaald in noot 19.

47. Zie bijv. de brief van Eumedion (beheerd vermogen leden: $€ 4$ biljoen) aan MSCI van 31 augustus 2017, beschikbaar via www.eumedion.nl/en/ public/knowledgenetwork/consultations/2017/2017-08-response-msciindex-consultation-non-voting-shares.pdf ('Eumedion is of the opinion that the right to vote at the AGM in itself is fundamental to the share ownership of listed companies and that shareholders' power should be proportionate to their economic interest'). Aldaar komt ook naar voren dat aanpassing van het indexgewicht wat Eumedion betreft de voorkeur heeft.

48. Vgl. www.blackrock.com/corporate/en-us/literature/publication/blk-apotential-solution-for-voting-rights-and-index-inclusion-issuesoctober2017.pdf.

49. Het rapport, met daarin vermeld de specifieke voorwaarden die gesteld worden aan de uitgifte van dual class-aandelen (aangeduid als weighted voting rights), is beschikbaar via www.hkex.com.hk/-/media/HKEXMarket/News/Market-Consultations/2016-Present/June-2017-ConceptPaper-on-New-Board/Conclusions-(December-2017)/cp2017061cc.pdf.

50. Zie www.sgx.com/wps/wcm/connect/sgx_en/home/highlights/news_ releases/sgx_clarifies_that_existing_secondary_listing_framework_ allows_dual_class_share_companies. Het verbod dat op basis van art. 64 (1) van de Singaporese Companies Act voorheen gold ter zake van afwijkingen van het principe van one share, one vote is in 2016 komen te vervallen. 


\section{Maandblad}

Ondernemingsrecht

divergentie is des te opmerkelijker, daar er weinig tijd tussen de verschillende consultatierondes zat en dus te verwachten valt dat er tussen de reacties overlap bestaat.

\section{Een kritische analyse}

\subsection{De competenties van indexconstructeurs}

Conceptueel kiezen passieve investeerders er niet voor om individuele aandelen te selecteren en aldus een hoger rendement dan de markt na te streven. $\mathrm{Zij}$ veronderstellen immers dat dit resultaat op de lange termijn niet mogelijk is. ${ }^{51}$ In plaats daarvan zijn zij vooral gericht op het realiseren van het rendement van de markt, dat immers het hoogst haalbare is, tegen lage kosten, zijnde die van het indexproduct. ${ }^{52}$ De transitie van S\&P Dow Jones, FTSE Russell en MSCI naar een meer actief selectieproces (niettegenstaande het graduele onderscheid tussen actief en passief beleggen ${ }^{53}$ ) betekent in zekere zin dat passieve indexfondsen afdrijven van hun oorspronkelijke doel (nog afgezien van de vraag of zij eenzijdig bevoegd zijn om specifieke corporate governance-standaarden vast te stellen). Bezien vanuit een passieve strategie zal dat beleggers uiteindelijk een lager rendement opleveren. Dat het ingewikkeld is op de lange termijn te bepalen welke beursvennootschappen het beste zullen presteren, kan een kort voorbeeld illustreren. Het aandeel Facebook ondervond kort na de beursgang een substantiële koersdaling, maar kwam daar snel weer bovenop. ${ }^{54}$ Anderzijds is de beursgang van Snap tot op heden geen onverdeeld succes gebleken. ${ }^{55}$ Juist om dergelijke, moeilijk in te schatten ontwikkelingen te beheersen is het indexbeleggen uitgedacht en zou er ruimte moeten blijven voor een ruim assortiment aan kapitaalstructuren. Het herziene MSCI-voorstel toont voorts aan dat het streven naar een zuiver proportionele verhouding tussen kapitaal en zeggenschap complicaties oproept. Te wijzen valt op de uitzondering voor loyaliteitsaandelen; het meewegen van de potentiële effecten daarvan zou het indexgewicht van Frankrijk - gelet op de loi Florange, die het loyaliteitsstemrecht tot uitgangs-

51. Vgl. noot 5

52. Vgl. noot 10

53. Zie noten 1 en 13 en bijbehorende tekst.

54. Facebook kent een 'traditionele' (P.A. Gompers, J. Ishii \& A. Metrick, Extreme governance: An analysis of dual-class firms in the United States, The Review of Financial Studies (23) 2010, p. 1051-1088) 1:10 dual class-structuur. De introductieprijs op 18 mei 2012 bedroeg \$ 38. Begin september 2012 kostte een aandeel \$ 18; in juni 2018 was dit - na een dip gedreven door zorgen omtrent privacy - opgelopen tot $\$ 190$.

55. Zie noot 19 en bijbehorende tekst voor de kapitaalstructuur van Snap. Het aandeel Snap sloot 2 maart 2017 (de dag van de beursgang) af op een prijs van $\$ 24,50$. Sindsdien heeft de koers moeite boven dat niveau te komen. punt verhief ${ }^{56}$ - substantieel verminderen. Het weren van dual class-vennootschappen uit enkele prominente indices is des te problematischer, gelet op de kruisverbanden die tussen indices bestaan (parent indexes) ${ }^{57}$ en de mogelijk beperkte kennis van beleggers daaromtrent.

\subsection{Een nieuwe benadering van dual class-structuren: de levenscyclus van de onderneming als uitgangspunt}

Vanuit de economische literatuur komen steeds meer signalen dat de kapitaalstructuur van de vennootschap beschouwd dient te worden in het licht van haar levenscyclus (life cycle bypothesis). ${ }^{58}$ Een vennootschap die in het prille begin van haar bestaan verkeert, is - bij gebrek aan (voorspelbare) kasstromen - veelal niet in staat om periodiek interestbetalingen te voldoen. Bovendien laat het zich in een dynamische markt lastig inschatten of het ontwikkelde product (de dienst) een succes zal blijken. De informatie-asymmetrieën tussen bestuurders en investeerders zijn substantieel. ${ }^{59} \mathrm{Bij}$ een volwassen vennootschap is de stand van zaken geheel anders. De kasstromen zijn voorspelbaar (en substantieel) en informatieasymmetrieën navenant kleiner. ${ }^{60}$ Zonder aanvullende maatregelen ontstaan er significante mogelijkheden om via dual

56. Zie in internationaal verband M. Becht, Y. Kamisarenka \& A. Pajuste, Loyalty shares with tenure voting - A Coasian bargain? Evidence from the loi Florange experiment, 2018, beschikbaar op http://papers.ssrn. com/('France the regulator introduced a law that gave favourable treatment to France the shareholder'); P.H. Edelman, W. Jiang \& R.S. Thomas, Will tenure voting give corporate managers lifetime tenure?, 2018, beschikbaar op http://papers.ssrn.com/; D.J. Berger, S.M. Davidoff \& A.J. Benjamin, Tenure voting and the U.S. public company, The Business Lawyer (72) 2017, p. 295-327; L.L. Dallas \& J.M. Barry, Long-term shareholders and time-phased voting, Delaware Journal of Corporate Law (40) 2015, p. 541-646; J. Delvoie \& C. Clottens, Accountability and short-termism: Some notes on loyalty shares, Law and Financial Markets Review (9) 2015, p. 19; zie in de Nederlandse literatuur J.M. de Jongh, Het loyaliteitsstemrecht. Een terreinverkenning, Ondernemingsrecht 2009/105; M.C. Schouten, Loyaal aan het eigen belang, Ondernemingsrecht 2010/122; J.M. de Jongh, Reactie: loyaal aan duurzame waardecreatie, Ondernemingsrecht 2010/152; M.C. Schouten, Loyaliteitsdividend, Ondernemingsrecht 2010/153; M. van Olffen, Loyaliteitsaandelen met een Frans sausje, Ondernemingsrecht 2013/67; A.A. Bootsma, Loyaliteitsstemrecht in het Franse wetsvoorstel-Florange, Ondernemingsrecht 2014/43.

57. Vgl. noot 16 en bijbehorende tekst.

58. Zie bijv. E.F. Fama \& K.R. French, Financing decisions: Who issues stock?, Journal of Financial Economics (76) 2005, p. 549-582, die een bestaand model om de kapitaalstructuur te beschrijven 'dood' verklaren; vgl. H. DeAngelo, L. DeAngelo \& R. Stulz, Dividend policy and the earned/contributed capital mix: A test of the life-cycle theory, Journal of Financial Economics (81) 2006, p. 227-254; H. DeAngelo, L. DeAngelo $\&$ R. Stulz, Seasoned equity offerings, market timing, and the corporate lifecycle, Journal of Financial Economics (95) 2010, p. 275-295.

59. Vgl. in dit verband A.A. Alchian \& H. Demsetz, Production, information costs, and economic organization, The American Economic Review (62) 1972, p. 777-795.

60. Zie voor een analyse van de verschillende factoren wat betreft de keuze tussen eigen en vreemd vermogen bijv. M.Z. Frank \& V.K. Goyal, Capital structure decisions: Which factors are reliably important?, Financial Management (38) 2009, p. 1-37. 
class-structuren private benefits te verwerven. ${ }^{61}$ Het life cycleperspectief is aldus nadrukkelijk breder dan de zuivere agencyleer, die immers met name relevant is voor volwassen concerns en een analytisch kader voor jongere ondernemingen goeddeels mist. De life cycle-invalshoek zou ook wel eens relevant kunnen zijn wat betreft het stemrecht. Zo stellen Cremers, Lauterbach en Pajuste dat dual class-mechanismen de stap van privaat naar publiek faciliteren en in de eerste jaren na de beursgang, ten opzichte van single class-vennootschappen, gemiddeld waarde toevoegen. $\mathrm{Na}$ een gemiddelde periode van negen tot tien jaar is dit veranderd in een korting, ${ }^{62}$ hetgeen overigens niet hoeft te betekenen dat aandeelhouders een matig rendement realiseren. ${ }^{63}$ Johnson, Karpoff en Yi vinden soortgelijke resultaten wat betreft het bestaan van beschermingsmaatregelen in het algemeen. ${ }^{64}$

Gelet op het life cycle-perspectief lijkt het onverstandig om, zoals nu gebeurt, aandelen van dual class-vennootschappen pertinent uit bepaalde indices te weren. Wanneer dual classmechanismen worden beschouwd als signaal dat een onderneming een periode van snelle groei - die gepaard gaat met hoge informatie-asymmetrieën - ingaat, riskeren passieve beleggers immers hun instapmoment te missen en daarmee lucratieve ontwikkelingen mis te lopen. Zelfs wanneer enkele dual classvennootschappen het niet zouden bolwerken, brengt het principe van beperkte aandeelhoudersaansprakelijkheid maar ongelimiteerd potentieel met zich dat op geaggregeerd niveau een aantrekkelijk rendement nog steeds tot de mogelijkheden behoort. ${ }^{65}$ Het life cycle-perspectief suggereert aldus primair een faciliterende omgang met dual class-structuren. Tijdige intrekking van bigh-voting stock kan bijvoorbeeld worden gestimuleerd door in de onderhandelingen daarover controlerende aandeelhouders een premie toe te kennen. Deze kan zowel zien op de koers - in de regel noteert high-voting stock

61. Vgl. par. 3.2. Zie ook DeAngelo, DeAngelo \& Stulz 2006, die opmerken dat wanneer de 25 grootste (gemeten naar marktkapitalisatie) Amerikaanse betalers van dividend niet zulke uitkeringen zouden hebben gedaan, hun liquide middelen $\$ 1,8$ biljoen zouden bedragen, $\$ 1,2$ biljoen meer dan hun langlopende schulden.

62. Zie M. Cremers, B. Lauterbach \& A. Pajuste, The life-cycle of dual class firms, 2017, beschikbaar op www.ssrn.com. De life cycle-benadering zou mogelijk (gedeeltelijk) ook tegenstrijdige resultaten in eerdere empirische studies kunnen verklaren (zie noot 29).

63. Men vergelijke de beslommeringen van Google. De introductieprijs in 2004 bedroeg omstreeks \$ 50. In juni 2018 was de koers gestegen tot $\$ 1150$. Zie ook noot 54-55.

64. Zie W.C. Johnson, J.M. Karpoff \& S. Yi, The lifecycle effects of firm takeover defenses, 2017, beschikbaar op www.ssrn.com. Zie eerder ook R. Daines \& M. Klausner, Do IPO charters maximize firm value? Antitakeover protection in IPOs, Journal of Law, Economics \& Organization (17) 2001, p. 83-120.

65. Op soortgelijke wijze is de favourite/long-shot bias (die stelt dat het menselijk brein in een selectieproces kansrijke mogelijkheden onderwaardeert en kansarme opties overwaardeert) hier minder relevant. hoger dan low-voting stock ${ }^{66}$ - als op de omwisselingsverhouding. Statutair is immers veelal vastgelegd dat conversie van high-in low-voting stock geschiedt in een een-op-eenverhouding. ${ }^{67}$ Controlerende aandeelhouders hoeven niet koste wat kost aan hun zeggenschap vast te houden. ${ }^{68}$ Een alternatief kan worden gevormd door statutaire horizonbepalingen (sunset provisions). Zij voorzien vooraf in de afbouw van een dual class-structuur. Dergelijke bepalingen kunnen gebaseerd zijn op tijdsverloop, het economisch belang, het intreden van een vooraf omschreven gebeurtenis of een combinatie daarvan. ${ }^{69}$ Het is dan ook enigszins opmerkelijk dat sunset provisions in de verschillende consultatierondes weinig aandacht hebben gekregen. Zij lijken immers bij uitstek geschikt om de positieve effecten van dual class-structuren te verzekeren en zouden in die zin een garantie moeten vormen voor indexopname. Opgemerkt zij wel dat sunset provisions doordacht geformuleerd dienen te worden. Het enkele tijdsverloop zegt bijvoorbeeld op zichzelf weinig over de levensfase en lijkt daarmee een ongeschikt criterium. Meer ligt het in de reden (maar ook hier zijn alternatieven denkbaar) om aan te sluiten bij factoren op ondernemingsniveau als vrije kasstromen en innovativiteit. $\mathrm{Nu}$ de life cycle-invalshoek een afweging tussen informatie- en faillissementskosten enerzijds en agency-kosten anderzijds voorstaat, ligt het daarnaast in de reden om duidelijke verplichtingen tot disclosure omtrent het economisch belang van de controlerend aandeelhouder op te nemen. ${ }^{70}$ Sunset provisions kunnen wat mij betreft overigens niet dwingend worden opgelegd, nu zij de vennootschap plotseling in een kwetsbare positie kunnen brengen. Bovendien zou het onder een life cycle-benadering principieel mogelijk moeten zijn (wanneer het karakter van de onderneming ingrijpend verandert) om midstream een dual class-structuur te introduceren. Dat derge-

66. Klassieke studies zijn T. Nenova, The value of corporate voting rights and control: A cross-country analysis, Journal of Financial Economics (68) 2003, p. 325-351 en L. Zingales, The value of the voting right: A study of the Milan stock exchange experience, The Review of Financial Studies (7) 1994, p. 125-148; zie recent bijv. A. Kalay, O. Karakaş \& S. Pant, The market value of corporate votes: Theory and evidence from option prices, The Journal of Finance (69) 2014, p. 1235-1271.

67. Voor de Forest City-casus, waarin de controlerende aandeelhouder een hedge fund steunde in het afbouwen van de dual class-structuur in ruil voor het ontvangen van aanvullende aandelen, zie E.A. Klingsberg, Index eligibility as governance battlefield: Why the system is not broken and we can live with dual class issuers, 2017, beschikbaar op www.corpgov.law. harvard.edu.

68. Vgl. Cremers, Lauterbach \& Pajuste (2017), die observeren dat dual classstructuren in meer dan $20 \%$ van de gevallen worden opgeheven; zie ook B. Amoako-Adu \& B.F. Smith, Dual class firms: Capitalization, ownership structure and recapitalization back into single class, Journal of Banking \& Finance (25) 2001, p. 1083-1111, die concluderen dat 'control changes are equally frequent for dual and single class firms, suggesting that dual class capitalization is not used to unduly entrench management'.

69. Over sunset provisions Bebchuk \& Kastiel 2017 (hoewel in de verplichte variant); zie ook A.W. Winden, Sunrise, sunset: An empirical and theoretical assessment of dual-class stock structures, 2017, beschikbaar op www.ssrn.com

70. In die zin Bebchuk \& Kastiel 2018. Zie in een Nederlandse context C.A. Schwarz, De impact van het vennootschappelijk belang: machtsverhoudingen, verantwoordelijkheid en aansprakelijkheid, Boom: Den Haag 2018. 


\section{Maandblad}

Ondernemingsrecht

lijke herkapitalisaties naar geldend Nederlands vennootschapsrecht zijn toegestaan, ${ }^{71}$ valt aldus te prijzen. Eventueel kan in het midstream kader worden gedacht aan een goedkeuringsrecht voor minderheidsaandeelhouders (formeel) of een uittreedrecht voor tegenstemmers (materieel). Aldus geeft de voorstander van herkapitalisatie een signaal af naar buiten dat hij verwacht dat de transactie waarde creëert. ${ }^{72}$

\subsection{Het onthouden van stemrecht aan indexbeleggers als alternatief?}

Zoals reeds werd aangestipt, kunnen beheerders van passieve beleggingsfondsen niet, ter zake van een individuele deelneming, 'uitstappen'. In het schema van Hirschman is de exitoptie afwezig. ${ }^{73}$ Dit zou kunnen betekenen dat loyale indexfondsen eerder geneigd zijn gebruik te maken van het voicemechanisme, ${ }^{74}$ dat dan uiteraard wel aanwezig dient te zijn. Anderzijds kan worden betoogd dat dergelijke fondsen geen prikkel kennen om toezicht op het management te houden. Met een (succesvolle) interventie bij een individuele onderneming zijn substantiële inspanningen gemoeid (hetgeen problematisch is met het oog op de kostenstructuur), maar de prestaties van het indexfonds als geheel veranderen daardoor nauwelijks; voorts profiteren concurrenten evenzeer. ${ }^{75}$ Het stemgedrag van indexfondsen is bovendien voorwerp geweest van debat. Enerzijds blijken passieve investeerders niet - zoals soms gedacht - slechts stemadviezen van bijvoorbeeld ISS te volgen. In voorkomende gevallen kunnen zij profiteren van kennis die is opgedaan door actieve fondsen die beheerd worden door dezelfde aanbieder. ${ }^{76}$ Anderzijds lijkt het een zware opgave voor indexfondsen om bijzondere expertise ten

71. Vgl. A.A. Bootsma, Loyaliteitsdividend, bijzondere stemrechtaandelen en de positie van minderheidsaandeelhouders. Midstream or IPO introduction, that's the question, $\mathrm{MvO} 2016$, afl. 7, p. 151-160; zie in gelijke zin Bootsma \& Keijzer 2017.

72. Zie A.M. Pacces, Exit, voice and loyalty from the perspective of hedge funds activism in corporate governance, Erasmus Law Review (10) 2016, p. $199-216$.

73. Zie A.O. Hirschman, Exit, voice, and loyalty. Responses to decline in firms, organizations, and states, Cambridge: Harvard University Press 1970, waarover A.R. Admati \& R. Pfleiderer, The 'Wall Street walk' and shareholder activism: Exit as a form of voice, The Review of Financial Studies (22) 2009, p. 2645-2685; A. Edmans, Blockholder trading, market efficiency, and managerial myopia, The Journal of Finance (64) 2009, p. 2481-2513. Voor een recente analyse, zie bijv. A.A. Bootsma, An eclectic approach to loyalty-promoting instruments in corporate law: Revisiting Hirschman's model of exit, voice and loyalty, Erasmus Law Review (7) 2013, p. 111-130; zie ook Pacces 2016.

74. Vgl. bijv. L.E. Strine, Can we do better by ordinary investors? A pragmatic reaction to the dueling ideological mythologists of corporate law, Columbia Law Review (114) 2014, p. $449-502$ ('Precisely because index funds do not sell stocks in their target index, those funds have a unique interest in corporations pursuing fundamentally sound strategies that will generate the most durable wealth for stockholders').

75. In die zin L.A Bebchuk, A. Cohen \& S. Hirst, The agency problems of institutional investors, Journal of Economic Perspectives (31) 2017, p. 89-102.

76. Zie bijv. P. Illiev \& M. Lowry, Are mutual funds active voters? The Review of Financial Studies (28) 2015, p. 446-485. aanzien van een individuele onderneming op te doen. ${ }^{77}$ In een tijdperk waarin informatiekosten aan belang winnen, neemt de ongeïnformeerdheid van indexbeleggers - de principal $\operatorname{costs}^{78}$ - toe. Inderdaad blijkt het stemgedrag van indexfondsen vooral waarde te creëren bij weinig gecompliceerde onderwerpen (low-cost governance).$^{79}$ Hun stemgedrag zorgt daarentegen voor waardevernietiging wanneer het meer complexe onderwerpen betreft (high-cost governance). ${ }^{80}$

Op basis van de hierboven aangehaalde overwegingen heeft Lund recent voorgesteld het stemrecht aan passieve indexbeleggers (nadrukkelijk niet aan beleggingsfondsen in het algemeen) in beginsel te onthouden; indien gewenst kunnen zij daarvoor echter in aanmerking komen. ${ }^{81}$ Wanneer tegelijkertijd high- en low-voting stock ter beurze zijn genoteerd, ontstaat concurrentie tussen aanbieders van indexproducten en kunnen aandeelhouders met verschillende niveaus van geïnformeerdheid bij de vennootschap betrokken worden zonder dat een efficiënte besluitvorming in het geding komt. ${ }^{82}$ Bovendien noteert high-voting stock veelal tegen een hogere koers dan low-voting stock, ${ }^{83}$ zodat wanneer op beide aandelen eenzelfde uitkering wordt gedaan, via low-voting stock een hoger dividendrendement kan worden gerealiseerd. ${ }^{84}$ Dit voorstel is evenmin vrij van haken en ogen. Zo kunnen indexfondsen niet meer als 'arbiter' bij activisme van hedge funds fungeren ${ }^{85}$ en kunnen controlerende aandeelhouders die opteren voor uitgifte van stemrechtloze aandelen hun economisch belang terugschroeven zonder controle te hoeven opgeven. ${ }^{86}$ Een en ander illustreert wel dat de hier beschreven ontwikkelingen ook een andere richting op hadden kunnen gaan.

\section{Conclusie}

$\mathrm{Na}$ een spoedig verlopen, door institutionele beleggers geïnitieerd consultatieproces zijn S\&P Dow Jones, FTSE Russell en MSCI ertoe overgegaan om het gebruik van dual class-structuren door beursvennootschappen in aandelenindices te ontmoedigen. Consensus over de vraag hoe in indexverband met gedifferentieerd stemrecht omgesprongen dient te worden, is

77. D. Lund, The case against passive shareholder voting, 2017, beschikbaar via www.ssrn.com ('BlackRock employs about 20 people who work on governance issues at some 14,000 companies (...) Given the number of companies (...), simply voting the shares, without even considering how to vote them, is an enormous task'); hierna: Lund 2017b.

78. Vgl. Goshen \& Squire 2016; Goshen \& Hamdani 2017; Sharfman 2017.

79. Zie Appel, Gormley \& Keim 2016.

80. Vgl. C. Schmidt \& R. Fahlenbrach, Do exogenous changes in passive institutional ownership affect corporate governance and firm value, Journal of Financial Economics (124) 2017, p. 285-306.

81. Vgl. Lund 2017b, die ook betoogt dat SEC-voorschriften passieve fondsen niet, zoals veelal wordt gedacht, dwingen tot het uitbrengen van hun stem.

82. Daarover M.C. Schouten, The mechanisms of voting efficiency, Columbia Business Law Review 2010, p. 763.

83. Zie noot 66 .

84. Zie Lund 2017a, die ook opmerkt dat het concurrentiemechanisme niet werkt wanneer enkel stemrechtloze aandelen ter beurze zijn genoteerd.

85. In die zin Pacces 2016 en Appel, Gormley \& Keim 2016; zie bijv. ook A. Brav e.a., Hedge fund activism, corporate governance, and firm performance, Journal of Finance (63) 2008, p. 1729-1775.

86. Zie Bebchuk \& Kastiel 2018. 


\section{Maandblad}

vooralsnog echter afwezig. Daarbij teken ik aan dat MSCI de (definitieve) resultaten van zijn consultatieproces op het moment van schrijven nog bekend dient te maken. De huidige ontwikkelingen lijken om verschillende redenen echter in een ongelukkige richting te leiden. De transitie van S\&P Dow Jones, FTSE Russell en MSCI naar een meer actief selectieproces betekent dat passieve fondsen afdrijven van hun oorspronkelijke doel. De indruk wordt gewekt dat indexsamenstellers in staat zijn om te bepalen welke beursvennootschappen het beste rendement bieden. Te verwachten valt dat deze benadering beleggers geld zal kosten. Beziet men de onderneming vanuit een life cycle-perspectief, dan lijkt het eveneens onverstandig om aandelen van dual class-vennootschappen uit de index te weren. Die benadering impliceert immers dat dual class-mechanismen een signaal vormen dat een onderneming een periode van snelle groei doormaakt. Door het weigeren van dual class-vennootschappen dreigen beleggers hun instapmoment te missen. Zinvoller zou het zijn geweest om de tijdige afbouw van dual class-structuren te verzekeren. Overigens zou een ontwikkeling de andere kant op - het in beginsel uitsluiten van indexfondsen van stemrecht -, hoewel evenmin ideaal, theoretisch eveneens denkbaar zijn geweest. Op die manier zouden beleggers met een verschillende mate van geïnformeerdheid bij de vennootschap kunnen worden betrokken en zouden passieve beleggers de mogelijkheid hebben gekregen een hoger dividendrendement te realiseren. Uiteindelijk blijft het echter uitkijken naar de op termijn ongetwijfeld te verschijnen empirische studies om de effecten van de hier besproken voorstellen in meer detail te analyseren. 